\title{
POLA PEMBINAAN TAHSIN ALQURAN DI KALANGAN MAHASISWA
}

(Analisis Pola Pembinaan pada Himpunan Qari Qariah Mahasiswa Sulawesi Tengah (HIQMAH)"

\section{Tamrin}

Isntitut Agama Islam Negeri (IAIN) Palu

\begin{abstract}
This paper describes the pattern formation of Tahsin Qur'an organized by the student Association HIQMAH as an institution that bring together people who have a talent and interest in the art of reading and writing the Qur'an. The description was -analytic descriptive study, with a focus on the activities undertaken tahsin Qur'an start from the recruitment process to the implementation of various scientific studies both of scientific seminars or meeting. It can be concluded that the Qari and Qariah of Student Association (HIQMA) Central Sulawesi carry out its activities in the form of regular coaching per week, their participation in the Musabaqah event until taklim program in accordance with programs determined in the meeting program. Qur'an recitations art that developed in the Islamic countries and Tahfidz Qur'an is very major activities that can be especially developing capabilities as well as the deepening of the sciences of the Qur'an and recitation for students.
\end{abstract}

Keyword: HIQMAH, Tahsin Qur'an 
Tulisan ini mendeskripsikan tentang Pola Pembinaan Tahsin Alquran yang diselenggarakan oleh Lembaga mahasis HIQMAH sebagai lembaga yang menghimpun bagi mereka yang memiliki talenta dan minat seni baca tulis Alquran. Pembahasan ini bersifat telaah deskriptif-analitif, dengan fokus pada kegiatan tahsin Alquran yang dilaksanakan mulai dari rekrut kaderisasi hingga pelaksanaan berbagai kajian ilmiyah baik seminar maupun temu ilmiyah. maka dapat disimpulkan bahwa Himpunan Qari dan Qariah Mahasiswa (HIQMA) Sulawesi Tengah melaksanakan kegiatannya dalam bentuk rutin pembinaan tiap pekan, keikutsertaan dalam iven Musabaqah hingga pada program taklim yang sesuai dengan program yang ditetapkan dalam rapat program. Seni Tilawah Alquran yang berkembang di belahan negeri Islam dan Tahfidz Alquran adalah kegiatan yang sangat utama teristimewa dalam mengembangkan kemampuan para mahasiswa serta pendalaman ilmuilmu Alquran dan tajwid.

Keyword: HIQMAH, Tahsin Alquran

\section{PENDAHULUAN}

Dalam sejarah perkembangan keIslaman, pembelajaran alQur'an merupakan tradisi tertua. Pada masa Rasulullah, para murid / sahabat berupaya memenuhi keinginannya untuk mempelajari dan memahami ayat-ayat al-Qur'an tahap demi tahap hingga memahami secara utuh.

Para sahabat melakukan proses pembelajaran al-Qur'an dari Rasulullah secara utuh dan teratur sesuai dengan kemampuan belajar mereka. Dalam situasi tersebut, Rasulullah kemudian membenarkan bentuk-bentuk pembacaan al-Qur'an mereka yang dalam tradisi 
keilmuwan dikenal dengan qiraat, Maka dalam tradisi keilmuwan al-Qur'an lahirlah apa yang dikatakan ilmu qiraat.

Ilmu qira'at merupakan salah satu cabang ilmu tertua dalam 'Ulum al-Qur'an, namun tidak banyak orang yang tertarik kepadanya, kecuali orang-orang tertentu saja, biasanya kalangan akademik. Banyak faktor yang menyebabkan hal itu, di antaranya adalah, ilmu ini tidak berhubungan langsung dengan kehidupan dan muamalah manusia sehari-hari, tidak seperti ilmu fiqih, hadis, dan tafsir misalnya, yang dapat dikatakan berhubungan langsung dengan kehidupan manusia. Hal ini dikarenakan ilmu qira'at tidak mempelajari masalah-masalah yang berkaitan secara langsung dengan halal-haram atau hukum-hukum tertentu dalam kehidupan manusia.

Sejarah penulisan dan penyusunan serta penyebaran alQur'an telah bermula dari zaman Rasulullah SAW. Pada zaman ini, penyusunan telah mula dilakukan oleh para sahabat Rasulullah SAW. Beliau menyuruh sahabat-sahabat agar menulis ayat-ayat alQur'an meskipun dalam media yang sangat sederhana seperti pada tulang, pelepah- pelepah, bani, kulit-kulit binatang dan sebagainya. Rasulullah SAW juga menghafal ayat- ayat tersebut dan meminta para sahabat yang lain menghafal ayat-ayat al-Qur'an.

Praktik yang biasa berlaku di kalangan para sahabat tentang penulisan al-Qur'an, menyebabkan nabi Muhammad melarang orang-orang menulis sesuatu darinya kecuali al-Qur'an, dan siapa yang telah menulis sesuatu dariku selain al-Qur'an maka ia harus menghapusnya.

Sahabat-sahabat yang menjadi para penulis wahyu pada masa itu ialah Umar bin Al-Khattab, Uthman bin Affan, Ali bin Abi Talib, Muawiyyah bin Abi Suffian, Zaid bin Thabit dan sebagainya.

Rasulullah SAW melarang para sahabat menulis selain dari 
pada ayat al-Qur'an karena khawatir akan bercampur aduk. Waiau bagaimanapun pengumpulan al-Qur'an di zaman Rasulullah bukan dalam bentuk mashaf seperti di zaman Saidina Utsman bin Affan karena jika terjadi kekeliruan, ia dapat diatasi langsung oleh Rasulullah. SAW. Pada masa kehidupan Rasulullah seluruh alQur'an sudah tersedia dalam bentuk tulisan. Demikian dalam perkembangan penulisan dan pembacaan al-Qur'an pada masa periode sahabat terus mengalami perkembangan. Baik dalam model irama pembacaan al-Qur'an maupun model penulisannya. Pada masa pemerintahan khalifah Ali bin Abi Thalib, bersamaan dengan kebutuhan ummat Islam atas kitab suci, ia pun memerintahkan untuk dilakukan penyempumaan syakl dan pemberian nuqat pada setiap huruf al-Qur'an. Tugas tersebut dibebankan kepada Abu Aswad Ad-Duali untuk membariskan al-Qur'an dan pada saat itu juga lahir ilmu i'rab al-Qur'an. Jadi dapat disimpulkan bahwa pada masa Ali hanya terjadi proses pembarisan al-Qur'an dan munculnya ilmu i'rab al-Qur'an. karena pada masa itu pemerintahan sedang menghadapi banyak masalah antara sesama umat Islam sampai terjadi perang siffin dan juga perang jamal. Hingga pada akhirnya al-Qur'an telah mengalami penyempumaan dan tanpa perkembangan dalam tanda baca dan memungkinkan kitab suci tersebut terus menyebar ke seluruh penjuru dunia Islam termasuk ke wilayah Indonesia.

Problema pembelajaran al-Qur'an di Indonesia saat ini, ketika penelitian menyebutkan bahwa tingkat buta huruf al-Qur'an di Indonesia terbilang tinggi. Data Badan Pusat Statistik (BPS) tahun 2013 menyebutkan ada sekitar 54 persen dari total populasi umat Islam di Indonesia yang tidak bisa membaca al-Qur'an. Direktur Jenderal Bimbingan Masyarakat (Bimas) Islam Kementerian Agama (Kemenag) RI, Machasin, menilai untuk mengatasi hal itu diperlukan peran aktif masyarakat. Ia menekankan 
bahwa Pemerintah hanya sebatas memfasilitasi. Sebab, membaca al-Qur'an tidak seperti ibadah besar semisal haji, yang penyelenggaraannya wajib dan rutin.

Machasin mengatakan, salah satu cara dari Kemenag untuk meningkatkan tingkat melek al-Qur'an adalah pencanangan program Gerakan Masyarakat Maghrib Mengaji (Gemar Mengaji). Program tersebut terinspirasi dari budaya sebagian besar masyarakat muslirn di Indonesia tempo dulu, yang kerap melakukan amalan tadarus alQur' an tiap bada shalat Maghrib.

Adapun gerakan Gemar Mengaji pertarna kali dideklarasikan oleh Menteri Agarna RI, Suryadharma Ali, di Jakarta pada 26 September 2012. Kementerian Agama RI mencanangkan program Gemar Mengaji bagi seluruh provinsi serta kabupaten/kota di Indonesia Harapannya, rnasyarakat akan kernbali terbiasa dengan budaya mengaji al-Qur'an tiap sesudah melaksanakan shalat maghrib. Ini dilakukan baik di masjid, rumah, sekolah, maupun kantor instansi swasta atau pemerintah.

Namun perlu diakui bahwa dalarn proses perkembangan dan semangat tersebut Gerakan Gemar Mengaji sangat perlu peran aktif masyarakat sendiri untuk memberantas buta huruf al-Qur'an. Hal ini disebabkan bahwa penerapan Gemar Mengaji antara lain bagi anak-anak dan remaja di sejumlah masjid atau Taman Pendidikan al- Qur'an (TPA) bahkan Perguruan Tinggi di seluruh Indonesia akan maksimal jika masyarakat membiasakan mengaji tiap maghrib di lingkungan keluarga.

Di perguruan tinggi kini telah bermunculan lembaga-lembaga yang memiliki semangat tinggi dalam memasyarakatkan baca tulis al-Qur'an. Mahasiswa berpartisipasi aktif dalam program Pelatihan dan Pengkajian Al-Qur'an, termasuk dalam organisasi

Himpunan Qari Qariah Mahasiswa (HIQMAH) Propinsi Sulawesi Tengah. Kini lembaga HIQMAH Propinsi Sulawesi Tengah 
telah melakukan berbagai pelatihan. Prestasi yang dilahirkan dari lembaga ini telah memenuhi berbagai kebutuhan masyarakat akan al-Qur'an dan nilai-nilai ajarannya. Berbagai metode dan cara yang ditempuh masing- masing bidang dalam lembaga tersebut untuk menciptakan kehidupan gemar baca tulis al-Qur'an.

Dari uraian tersebut di atas, maka dapat dirumuskan masalah bagaimana bentuk pembinaan tahsin al-Qur'an pada Himpunan Qari Qariah Mahasiswa (HIQMAH) Sulawesi Tengah.

Penelitian ini memiliki signifikansi yang sangat besar terutama ada dua hal yang sangat signifikan sebagai berikut: Signifikansi Teoritis yang dimaksudkan adalah bahwa secara teoritis penelitian ini diharapkan dapat menambah wawasan khususnya di Perguruan Tinggi untuk dijadikan sebagai bahan perbandingan pengungkapan teori. Dan Signifikansi Praktis bahwa penelitian ini dapat memberikan nilai tambah dan sekaligus sebagai bahan evaluasi terhadap apa yang telah diterapkan di lembaga Himpunan Qari Qariah Mahasiswa (HIQMAH) Propinsi Sulawesi Tengah yang selama ini sudah melakukan kegiatan pembinaannya.

\section{PEMBAHASAN}

Kajian tentang pengajaran al-Qur'an dalam kajian epistimelogi, ontologis dan aksiologis pada lembaga kajian alQur'an telah dilakukan, diantaranya Milla Bekti, Penerapan Metode Sintesis Dalam Pembelajaran Baca Tulis al-Qur'an di Madrasah Diniyah Nurul Huda Ciptomulyo Malang, ia menyatakan bahwa Metode sintesis merupakan salah satu metode dalam pembelajaran baca tulis al-Qur'an yang dimulai dengan mengenalkan bunyi-bunyi huruf Hijaiyah kemudian dirangkai menjadi kata dan kalimat. Metode sintesis ini banyak digunakan oleh lembaga-lembaga pendidikan dalam pembelajaran baca tulis 
al-Qur'an di seluruh Indonesia. Data penelitian ini berupa fenomena tentang penerapan metode sintesis dalam kegiatan belajar mengajar dan evaluasi, serta faktor-faktor pendukung dan penghambat penerapan metode sintesis dalam pembelajaran baca tulis al-Qur'an. Hasil penelitian ini menunjukkan bahwa dalam kegiatan belajar mengajar baca tulis al-Qur'an guru menggunakan metode bunyi- sintesis, yaitu dimulai dengan pengenalan bunyibunyi huruf Hijaiyah kemudian dirangkai menjadi kata dan kalimat. Di samping itu, guru rnenggunakan dua sistem pengajaran dalam kegiatan belajar rnengajar, yaitu sistem individual (privat) dan sistern klasikal. Sedangkan dalam pembelajaran menulis huruf al-Qur'an guru "penelitian yang bersifat fleksibel, terbuka dan dapat dikondisikan berdasarkan lapangan penelitian"

Kَسَّنَ - Kata tahsin secara bahasa diambil dari kata kerja (يُحَسِّنُ - نَحَسِينًَا memperindah atau membuat lebih baik dari semula. ${ }^{2}$

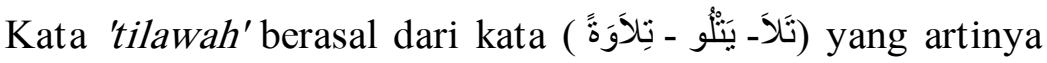
membaca atau bacaan. Adapun tilawah secara istilah adalah membaca Al Qur'an dengan bacaan yang menampakkan hurufhurufnya dan berhati-hati dalam melafadzkannya agar lebih mudah untuk memahani makna-makna yang terkandung di dalamnya. ${ }^{3}$

Dari dua definisi yang telah disebutkan tersebut, bisa disimpulkan bahwa makna tahsin tilawah adalah upaya memperbaiki atau membaguskan bacaan Al Qur'an dengan baik dan benar. Dasar penerapan pelaksanaan tahsin Alquran ini semata-mata mewujudkan firman Allah swt dalam surah Al Muzzammil ayat 4.

${ }^{1}$ Imron Arifin, penelitian kualitatif Dalam Ilmu-ilmu Sosial dan Keagamaan, Cet. III, (Malang:Kalimasada Press, 1996), 40.

${ }^{2}$ Lihat Mu'jam Al Wasith (1:174); Qamus Al-Munir, hal 265

${ }^{3}$ Lihat Mu'jam Al Wasith (1:187); 
Dalam ayat tersebut, Allah menggunakan lafadz rattil dengan penggunaan kalimat kerja perintah. Allah memerintahkan kita untuk membaca Al Qur'an dengan tartil yang sebenar-benarnya. Allah telah memerintahkan kepada setiap pembaca Alquran untuk menggunakan cara-cara tartil. Membaca Alquran dengan cara memahami mad (panjang pendek dari setiap huruf), makharij Huruf (menyebutkan huruf sesuai tempat keluarnya) dan ahkam huruf (membaca kata terkait dengan kata lain). Membaca Al Qur'an dengan tartil yang sebenar-benarnya seorang muslim dituntut untuk mempelajari bacaan Al Qur'an dengan baik dan benar yang dalam ini diistilahkan dengan tahsin tilawah Al Qur'an.

Selain istilah tahsin tilawah Alquran di atas, istilah yang serupa yang memiliki makna upaya memperbaiki bacaan Alquran adalah mujawwad. Lafadz mujawwad secara bahasa berasal dari kata جَّوَد يُجَوِدِ - تَجْوِيدًا memperbaiki, secara istilah, tajwid menurut para ulama ahli Al Qur'an adalah mengucapkan setiap huruf dari makhraj (tempat keluarnya huruf) dengan cara pengucapan benar, dengan memenuhi seluruh hak dari huruf tersebut (sifat al-huruf adalah istilah absolut huruf yang selalu menempel misalnya hams, jahr, isti'la, dan sebagainya) dan menunaikan seluruh mustahak-nya (sifat kondisional huruf yang sewaktu-waktu berubah seperti idzhar, iqlab, ikhfa', yang disebut dengan ahkam al-huruf) dengan tanpa berlebihan dan tanpa takalluf (mempersulit diri) serta tanpa ta'assuf (semaunya sendiri).

Imam Abu Amr Ad-Dani menjelaskan mengenai masalah yang hendaknya dijauhi para ahli Al Qur'an ketika mengajarkan Al Qur'an, beliau berkata: Tajwid bukanlah dengan mengunyahngunyah lidah, bukan memperdalam mulut, bukan membengkokbengkokkan dagu, bukan menggetar-getarkan suara, bukan memulurkan syiddah, bukan memotong-motong madd, bukan 
memperpanjang dengan ghunnah, bukan menggemukkan ra', bukan bacaan yang dijauhi karakter manusia nomal, bukan pula bacaan yang ditolak telinga dan hati nurani. Akan tetapi, tajwid adalah bacaan yang mudah, enak, manis, lembut, tanpa menungyahngunyah, tanpa mengulum-ngulum, tanpa ta'assuf, tanpa takalluf, tanpa dibuat-buat, tanpa berlebihan, dan tidak keluar dari karakter normal orang arab dan ucapan orang-orang yang fasih dari segala aspek qiraat. $^{4}$

Seorang bisa sampai pada materi tajwid secara utuh dan benar harus dengan memperbanyak latihan dan talaqqi (bertemu langsung dengan guru) dari guru yang mutqin (menguasai ilmunya) dan memiliki keahlian dalam pengajaran ilmu tajwid. ${ }^{5}$

Membaca Alquran dengan suara merdu dan berirama yang dalam istilah lainnya juga dikenal dengan taghanni atau tilawah bukanlah hal yang baru dalam sejarah Islam. Pada zaman Rasulullah SAW, kegiatan semacam itu sudah dilakukan. Bahkan, dalam sebuah riwayat disebutkan, Allah SWT menyukai orang- orang yang membaguskan suaranya ketika membaca Alquran.

"Tidaklah Allah mendengarkan sesuatu sebagaimana Dia mendengarkan Nabi-Nya membaguskan bacaan Alquran dan mengeraskan suaranya." (HR Bukhari 7544, Muslim 792). Riwayat lain menyebutkan, "Bukan golongan kami, orang yang tidak taghanni dalam membaca Alquran.” (HR Bukhari 350).

Meskipun taghanni kerap diartikan dengan membaguskan suara bacaan Alquran, namun kalangan ulama berbeda pendapat

${ }^{4}$ An-nasyr, juz II, hal 303

${ }^{5}$ Bobby Herwibowo, Tehnik Quantum Alquran halaman 121 yang dilandasi dalam sebuah hadis bahwa Rasulullah senantiasa ber-talaqqi dengan malaykat Jibril di setiap tahun dan membacanya dua kali setahun sampai aku menemui ajalku. atau dapat dilihat pada buku 9 Cara Praktis Menghafal Alquran, (Jakarta: Gema Insani Press, 2005) halaman 31. 
dalam mejelaskan makna kata tersebut. Beberapa dari mereka mengatakan, taghanni sama maknanya dengan tartil yang berarti membaca Alquran secara perlahan dan tanpa tergesa-gesa.

Sebagian ulama lainnya berpendapat, taghanni tidak sekadar diartikan membaca Alquran secara tartil, tetapi juga dengan mengamati aturan tajwid dan mempercantik suara bacaan. Sementara, ada pula ulama yang menyatakan bahwa taghanni berarti membaca Alquran dengan hati yang senang.

"Kendati berbeda pendapat mengenai arti kata taghanni, namun semua ulama sepakat bahwa membaca Alquran dengan suara yang indah merupakan amalan yang dianjurkan," ujar pakar Islam asal Turki, Mehmet Paksu, dalam ulasannya, Reciting the Qoran with Taghanni.

Imam Nawawi menuturkan, semua ulama sepakat bahwa memperindah suara dalam membaca Alquran diperbolehkan dalam batas-batas tertentu. Jika batas-batas tersebut dilanggar (seperti mengabaikan tajwid, menambahkan atau mengurangi satu huruf) maka bacaan seperti itu menjadi haram hukumnya.

Yang menjadi pertanyaan saat ini adalah sejak kapan penerapan irama dan lagu dalam bacaan Alquran mulai dilakukan. Belum ada literatur yang secara pasti menyebut demikian. Akan tetapi, sejarah mencatat bahwa orang yang pertama kali menyenandungkan Alquran dengan irama yang indah adalah Rasulullah SAW sendiri. Abdullah bin Mughaffal pernah mengilustrsikan kemerduan suara Nabi ketika melantunkan surah alFath mampu membuat unta yang beliau tunggangi menjadi terperanjat.

Ketika Rasulullah SAW masih hidup pun, banyak qari atau pembaca Alquran yang mahir di bidangnya. Di antaranya adalah Abdullah ibnu Mas'ud RA dan Abu Musa al-Asy'ari RA. Dalam sebuah riwayat dikisahkan, Rasulullah SAW pernah lewat ketika 
Abu Musa sedang membaca Alquran. Nabi pun berhenti untuk mendengarkan bacaan sahabatnya itu. Beliau lalu bersabda, "Sungguh ia (Abu Musa) telah diberi keindahan suara sebagaimana keindahan suara keturunan Nabi Daud.” (HR Bukhari 5048, Muslim 793).

Beberapa waktu setelah itu, ketika Abu Musa datang kepada Rasulullah, Nabi pun mengabarkan kepadanya bahwa beliau telah men dengarkan bagusnya bacaan Abu Musa. Abu Musa lalu berkata, "Andai aku tahu engkau sedang mendengarkannya, tentu aku akan benar-benar memperindah bacaanku."

Rasulullah SAW tidak mengingkari pernyataan sahabatnya tersebut. Ini menunjukkan bahwa memperindah bacaan Alquran adalah hal yang dianjurkan supaya dapat menghasilkan kekhusyukan bagi pembaca dan pendengarnya.

Ayat - ayat Alquran dengan susunan kalimat dan kata yang teratur tersebut diturunkan oleh Allah swt telah menjadi hal yang seimbang dengan struktur fisik (rongga ucap dan rongga nafas) manusia. Susunan ayat-ayat Alquran telah tersusun harmonis dengan kemampuan baca manusia, terlebih dibacakan dengan irama.

Suara merdu dan indah yang dilantunkan oleh sahabatsahabat rasulullah ketika membaca ayat-ayat Alquran tidak saja menjadi suatu keharusan tetapi juga telah dicontohkan dan menjadi warisan dari leluhur para nabi terdahulu yaitu suara nabi Daud. Antara suara nabi Daud dan apa yang telah disampaikan oleh sahabat - sahabat dalam membaca Alquran mencerminkan bahwa tehnik bersuara, tehnik mengucapkan suatu kalimat/ayat memiliki kesamaan. Menurut Raghib Assirjani, tehnik olah vokal dalam membaca Alquran memerlukan kemampuan olah tubuh atau rongga mulut yang sesuai sehingga mengeluarkan irama yang indah. ${ }^{6}$

6 Raghib Assirjani, Sumbangan Peradaban Islam kepada Dunia, Pustaka Alkautsar, 277. 
Ketika Rasulullah mengungkap kelembutan dan kejernihan suara sahabat Abu Musa Al-Asy'ari dalam membaca ayat-ayat Alquran menimbulkan kesan bahwa irama yang diperagakan tersebut memiliki ciri dengan irama nabi Daud. Dalam riwayat dikatakan bahwa sampai-sampai Rasulullah lambat kembali ke rumah menemui isterinya dikarenakan kagum dan terharunya mendengarkan suara sahabat selembut suara nabi Daud. Kesan yang ditimbulkan oleh pendengar ketika dibacakan ayat Alquran secara merdu memiliki daya tarik dan pikat yang istimewa. Dalam riwayat pun disebutkan bahwa sahabat yang memeluk Islam banyak disebabkan karena mereka mendengarkan lantunan ayat Alquran yang disampaikan dengan irama yang indah. ${ }^{7}$ Di dalam Alquran, Allah menyebutkan dalil tentang perintah membaca Alquran dengan menggunakan irama yang teratur disampaikan dalam struktur kalimat perintah dengan menggunakan lafadz rattil. Demikian pula disampaikan oleh seorang ulama terkemuka Hasan Albanna yang menekankan agar ummat Islam merasa dekat dan merasa memiliki Alquran secara penuh dengan mewujudkan cara baca yang benar. Membaca Alquran harus dengan teratur, tidak tergesa-gesa dan menciptakan situasi yang khusu' baik dibaca di dalam shalat maupun diluar shalat. ${ }^{8}$

Ibnu Katsir berkata: "Bacalah al-Qur'an pelan-pelan. Terdapat riwayat yang menceritakan bacaan Nabi Saw. bahwa beliau membaca al-Qur'an dengan perlahan-lahan." Dalam Shahih Al-Bukhari dari Anas Radhiallaahu 'anhu dia ditanya tentang bacaan Nabi Saw. maka Anas menjelaskan bacaan Nabi panjang-panjang.

Dalam melambatkan bacaan terdapat keutamaan yang besar. Kedudukan pembaca al-Qur'an di akhirat sangat tinggi sesuai

${ }^{7}$ Islam Khothob, Keutamaan Membaca Alquran dalam Alquran dan Terjemahannya, (Jakarta: Dunia Purtaka, tth), 105

${ }^{8}$ Majdi Alhilali, Agar Alquran Menjadi Teman, (Jakarta: Serambi Ilmu Semesta, tth), 270. 
dengan bacaan yang dilambatkannya waktu di dunia. Dalam AlMusnad dari Abi Said bahwa Nabi Saw. bersabda:

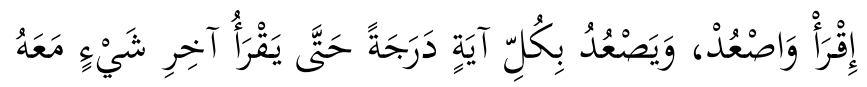

Artinya:

“(Dikatakan kepada pembaca al-Qur'an apabila masuk) surga: 'Bacalah! dan mendakilah, maka ia mendaki dengan setiap ayat satu derajat hingga ia membaca ayat terakhir yang ia hafal."

Seyogyanya menekankan bacaan dan memperbagus suara karena hal itu menambah kebagusan al-Qur'an hingga diterima pendengarnya serta meninggalkan bekas dalam hati. Dalam Sunan An-Nasa'i dan Ad-Darimi serta Al-Mustadrak Al-Hakim dari Barra' berkata: "Saya mendengar Rasulullah Saw. bersabda:

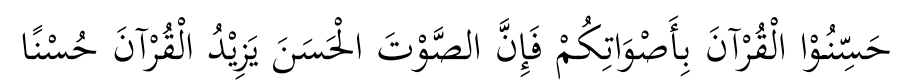

Artinya:

"Baguskanlah al-Qur'an dengan suaramu, karena suara yang bagus menambah keindahan al-Qur'an.",

Dalam Sunan Abi Daud dari Abu Lubabah bahwa Nabi Saw.

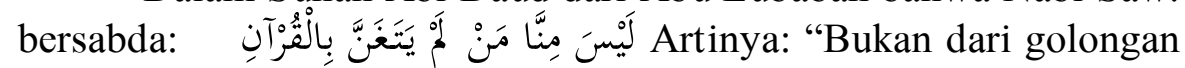
kami orang yang tidak melagukan al-Qur'an." An-Nawawi mengisahkan dari Jumhurul Ulama bahwa makna "lam yataghanna" adalah yang tidak membaguskan suaranya ketika membaca alQur'an.

Rasulullah Saw. qudwah (teladan) dalam hal ini. Dalam Shahih Al-Bukhari dari Barra' Ibnu 'Azib berkata: "Saya mendengar Rasulullah Saw. membaca dalam shalat isya' "At-Tiin waz Zaitun", tidak pernah kudengar seseorang yang lebih bagus suaranya dari beliau."

\footnotetext{
${ }^{9}$ Shahih al-Bukhari, Jami' Shagir jilid 3 hadis 3140.
} 
Dalam Shahih Al-Bukhari dan Muslim dari Abdullah Ibnu Mughaffal berkata: "Saya melihat Rasulullah Saw. di atas unta yang sedang berjalan sedang beliau membaca surat Al-Fath atau sebagiannya dengan bacaan yang lembut. Beliau Saw. membacanya dengan melagukannya."

At-Tarji' memiliki makna keadaan Nabi (yang terguncang) di atas unta sehingga menimbulkan getaran suara dan makna menekankan sesuai panjang dan pendeknya, dan ini yang terjadi.

Ibnu Hajar mengisahkan hal ini dan menguatkan yang kedua karena lebih sesuai dengan kenyataan, karena Rasul pernah berbisik:

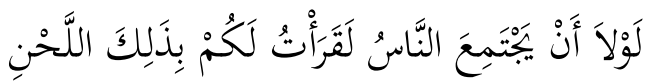

Artinya:

"Kalau sekiranya tidak menyebabkan manusia berkumpul niscaya kubaca kepada kalian dengan nada itu."

Maksudnya lagu, dalam riwayat lain terdapat kata at-tarji'. Kemudian dikeluarkan oleh At-Tirmidzi dalam Asy-Syamail, AnNasa'i, Ibnu Majah dan Ibnu Abi Daud, ini adalah lafazhnya dari hadits Ummu Hani: "Aku pernah mendengar suara Rasulullah yang sedang membaca al-Qur'an -ketika aku tidur di atas ranjangdengan melagukannya." Ibnu Abi Jumrah berkata: "Makna at-tarjii' adalah membaguskan suara."

Rasulullah Saw. memuji kepada sahabat yang memiliki suara bagus. Al-Bukhari dan Muslim meriwayatkan dari Abi Musa AlAsy'ari bahwasanya Rasulullah Saw. berkata kepadanya: "Sungguh saya diberi seruling dari seruling-seruling keluarga Nabi Daud." Beliau Saw. menunjuk pada keindahan suara sahabat itu.

Ibnu Majah dalam Sunannya meriwayatkan dari 'Aisyah Ra. berkata: "Saya pernah terlambat ke Rasulullah satu malam setelah isya' beliau bertanya: "Dimana engkau berada?" Saya menjawab: "Saya mendengar bacaan dari salah seorang sahabatmu, aku belum pernah mendengar suara dan bacaan sebagus dia, kemudian 
Rasulullah berdiri lalu saya mengikutinya hingga beliau mendengarnya sendiri. Kemudian beliau menoleh pada saya seraya bersabda: "Ini adalah Salim budak Abi Hudzaifah, segala puji bagi Allah yang menjadikan orang sepertinya dalam umatku." Bushiri berkata: "Isnad hadits ini shahih para perawinya terpercaya. Ibnu Katsir berkata: Sanadnya jayyid."

Imam An-Nawawi berkata: "Para ulama dari kalangan salaf (dahulu) maupun khalaf (belakangan) dari kalangan sahabat, tabi'in, dan orang-orang setelah mereka di penjuru negeri muslim sepakat atas sunnahnya membaguskan suara dengan al-Qur'an, perkataan dan perbuatan mereka ini sangat mashur. Kami memiliki perbendaharaan tentang hal ini. Dalil-dalil dari hadits tentang hal ini terperinci baik yang khusus maupun yang umum."

Dalam Shahih Muslim dari Aisyah Ra. bahwa Nabi Saw.

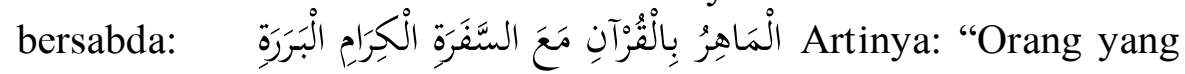
mahir membaca al-Qur' an bersama para malaikat yang mulia."

Ibnu Hajar berkata: "Orang yang mahir/piawai disini maksudnya baik bacaan dan hafalannya." Tetapi jika perubahan irama mengakibatkan pelanggaran terhadap makna dengan menyembunyikan sebagian huruf atau menyelewengkannya atau tindakan lainnya yang menyebabkan makna berubah atau menyerupai penyanyi dan orang yang bercanda maka sesungguhnya ia tercela bukannya terpuji.

Imam An-Nawawi berkata: "Para ulama berkata: 'Sunnah hukumnya membaca al-Qur'an dengan membaguskan suara dan urutannya selama belum keluar dari batas bacaannya hingga berlebihan. Jika melampaui batas sehingga menambah satu huruf atau menyembunyikannya maka hal itu haram'."

Adapun bacaan dengan berbagai dialek Imam Asy-Syafi'i berkata: "Saya tidak menyukainya. Sahabat-sahabat kami berkata: 'Kami tidak berhujjah dengan dua pendapat tetapi ada 
keterangannya bahwa jika berlebihan hingga melampaui batas maka itulah yang tidak disukai dan jika tidak melanggar maka tidak dibenci'."

Al-Mawardi dalam kitabnya Al-Hawi berkata: "Bacaan dengan lagu tertentu, jika hal itu menyimpang dari lafazh-lafazh alQur'an dari bentuknya dengan memasukkan harakat dan menghapusnya atau memendekkan yang panjang dan memanjangkan yang pendek, berlebihan hingga menyembunyikan sebagian lafazh dan menimbulkan kerancuan makna, maka hal itu haram hukumnya dan pembacanya menjadi fasiq serta yang mendengarkan berdosa karena keluar dari aturan yang lurus kepada yang bengkok. ${ }^{10}$

Jika tidak keluar bacaannya dari lafazh-lafazhnya tetapi hanya dengan melambatkan bacaan maka hal itu mubah (boleh) karena dia menambah lagu untuk membaguskan."

Imam An-Nawawi mengomentari hal ini dengan mengatakan: "Perkataan ini sebaik-baik pemecahan atau penengahan. Bagian pertama ini, bagian dari bacaan yang haram merupakan bencana yang diujikan kepada orang awam yang bodoh yang bertindak serampangan dengan membacanya untuk jenazah dan di waktu pesta. Ini merupakan bid'ah yang diharamkan secara jelas. Pada setiap pendengar yang membiarkan hal ini berdosa sebagaimana dikatakan Al-Mawardi dan juga bagi yang sanggup menghilangkannya atau mencegahnya namun tidak berbuat apapun."

Ibnu Katsir berkata: "Tujuan yang diminta dalam agama adalah membaguskan suara yang membangkitkan semangat untuk merenungi al-Qur'an dan memahaminya, khusyu' dan penuh dengan ketundukan serta kepatuhan terhadap perintahnya. Sedangkan menyuarakan al-Qur'an dengan patokan lagu dan irama yang bersifat hiburan dan aturan-aturan seperti musik dan yang

${ }^{10}$ Lihat Alquran Surah Al-Zumar ayat 28 
menjalankan madzhab ini, maka al-Qur'an terlalu suci dan agung untuk diperlakukan seperti itu. Dan telah datang sunnah yang menganggap hal itu dosa."

Tidak diragukan lagi bahwa tujuan dari memperbagus suara ketika membaca al-Qur'an dengan tajwidnya untuk mendorong pendengar agar membawanya untuk merenungkannya, tunduk dan terkesan dengannya. Alangkah bahagianya orang yang akalnya terikat oleh al-Qur'an kemudian hatinya menjadi lembut karenanya. Perlu diketahui oleh pembaca al-Qur'an sejauh mana ia terkesan ketika membacanya sejauh itu pula bacaannya akan berkesan kepada yang mendengarkannya.

Menurut Ibnu Katsir, ayat ini adalah seruan kepada setiap orang untuk menyatakan bahwa perkataan yang baik adalah perkataan yang mengandung manfaat. Perkataan yang memiliki kegunaan kontinue bagi seseorang, ia konsisten dengan perkataan tersebut dan selaras dengan perbuatannya. Bukan perkataan yang mungkar dimana ia sendiri melanggar kemungkaran tersebut. Seseorang yanfg mengajak kepada jalan kebenaran Tuhan dan senantiasa menyeruh kepada kebaikan dan berupaya menghindarkan dari kemungkaran. ${ }^{11}$

Sedangkan orang yang telah dikuasai setan kemudian melupakan Allah dan menjadi penyeru pada suaranya agar manusia kagum, maka alangkah ruginya perbuatan itu dan alangkah buruknya tempat kembalinya.

Dalam Shahih Muslim dari Abi Hurairah berkata: "Saya mendengar Rasulullah Saw. bersabda:

${ }^{11}$ Imaduddin Abul Fida Ismail bin al-Khatib Abu Hafs Umar bin Katsir asy-Syafi'i al-Quraisyi ad-Dimasyqi, Tafsir Alquran al-Azim almasyhur bi tafsir Ibnu Katsir Jilid II (kairo: Dar Syuruq, 1999), 22 


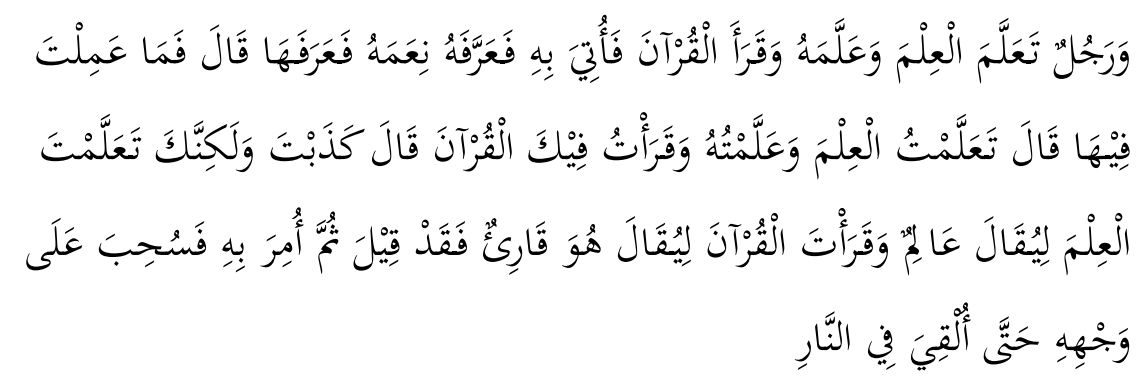

Artinya:

Kemudian didatangkan seorang yang belajar al-Qur'an danmengajarkannya, lalu Allah memperlihatkan nikmat yang telah dikaruniakan kepadanya. Allah bertanya: 'Untuk apa engkau berbuat dalam hal ini?' Ia menjawab: 'Aku belajar dan mengajarkan ilmu yang kudapat serta membaca alQur'an untukMu'. Allah menjawab: 'Engkau dusta, sesungguhnya engkau belajar agar dikatakan 'alim dan engkau membaca al-Qur'an agar dikatakan seorang qari', kemudian diperintahkan agar ia diseret dan dilempar ke Neraka."

Al-Ajuri berkata: "Seyogyanya bagi yang dikaruniai oleh Allah SWT. suara yang baik ketika membaca al-Qur'an agar mengetahui bahwa Allah telah mengaruniakan kebaikan khusus padanya maka hendaknya ia mengetahui kadar keistimewaan Allah baginya. Bacalah al-Qur'an semata karena Allah bukan untuk dipuji manusia. Berhati-hatilah dari kecenderungan untuk didengarkan orang agar memperoleh pujian, untuk mendapat dunia (harta), perasaan suka dipuji, untuk memperoleh kedudukan di dunia, hubungan dengan penguasa, lebih dari masyarakat umumnya. Barangsiapa cenderung kepada yang aku peringatkan maka aku khawatir suaranya yang bagus malah menjadi fitnah. Sedangkan suaranya akan memberi manfaat baginya jika ia takut kepada Allah SWT dalam keadaan sendiri atau bersama yang lain. Yang diminta darinya agar ia memperdengarkan al-Qur'an untuk memperingatkan 
orang-orang yang lalai agar berpaling dan mencintai apa yang dicintai Allah SWT menjauhi apa yang dicegahnya. Siapa yang memiliki sifat ini maka suaranya yang bagus bermanfaat baginya sendiri dan manusia.

\section{BENTUK NAGHAM DALAM TAHSIN AL-QURAN}

Pengetahuan, pengalaman dan pergerakan kejiwaan seseorang yang melagukan nyanyian ataupun nagham timur tengah lainnya tidaklah mencapai puncak setingkat pengalaman dan pengetahuan dalam penerapan ilmu tajwid. Sehingga makna yang pantas diberikan adalah nagham (irama) Alquran dengan menerapkan ilmu-ilmu tajwid dan tidak mengabaikan atau sengaja melanggar aturan-aturannya.

Menurut Ibnu Manzur dalam lisan al-arab dinukilkan oleh Dr Basyar Awad Ma'ruf, al-Bayan fi Hukm at-Taghanni bi Alquran, menyatakan bahwa ada dua teori tentang asal mula munculnya nagham Alquran. Pertama, sejarah nagham dinyatakan bahwa sumber nagham Alquran itu sendiri berasal dari ghina atau nyanyian yang turun temurun dilantunkan oleh bangsa Arab. Kedua, nagham terinspirasi dari nyanyian budak-budak kafir yang menjadi tawanan perang. Kedua teori tersebut menegaskan bahwa lagu-lagu Alquran berasal dari khazanah tradisional Arab. Dengan teori ini pula ditegaskan bahwa lagu-lagu Alquran idealnya bernuansa irama Arab. Sehingga apa yang pernah ditawarkan Mukti Ali dalam sebuah kesempatan pertemuan ilmiah tentang pribumisasi lagu-lagu Alquran tidak dapat diterima. Pada Masa akhir ini sesuai dengan perkembangan maka melalui teori konvergensi asal bersesuaian dengan nagham arab klasik. ${ }^{12}$

Secara teori, bahwa setiap nada dapat ditranformasikan kepada tangga nada yang sesuai secara tepat dan utuh. Akan tetapi

12 Bustaman Ismail, Mengenal Nagham (Irama) Al Quran dan Kilasan Sejarahnya, diunduh tanggal 2 Nopember 2016. 
tidak demikian dengan nagham Alquran. Tidak bukti sejarah yang menyatakan bahwa nagham Alquran telah disusun dalam suatu tangga nada. Olehnya, perkembangan nagham ke seluruh ummat Islam sampai saat terwujud melalui metode metode sima'i, talaqqi, dan musyahafah.

Pada zaman Rasulullah SAW, Abdullah bin Mughaffal pernah mengilustrasikan suara Rasulullah dengan terperanjatnya unta yang ditunggangi Nabi ketika Nabi melantunkan suroh Al Fath. Para sahabat juga memiliki minta yang besar terhadap ilmu nagham ini. Sejarah mencatat sejumlah sahabat yang berpredikat sebagai qari', diantaranya adalah : Abdullah Ibnu Mas'ud dan Abu Musa Al Asy'ari. Pada periode tabi'in, tercatat Umar bin Abdul Aziz dan Safir Al Lusi sebagai qari' kenamaan. Sedangkan periode tabi' tabi' in dikenal nama Abdullah bin Ali bin Abdillah Al Baghdadi dan Khalid bin Usman bin Abdurrahman.

Pada abad ke-20, kedua model lagu tersebut masuk ke Indonesia. Transmisi lagu-lagu tersebut dilakukan oleh ulama-ulama yang mengkaji ilmu-ilmu agama di sana yang pulang ke tanah air untuk mengembangkan ilmunya, termasuk seni baca Alquran. Lagu Makkawi sangat digandrungi di awal perkembangannya di Indonesia karena liriknya yang sangat sederhana dan relatif datar. Lagu Makkawi mewujud dalam barzanji. Beberapa qari' yang menjadi eksponen aliran ini adalah : KH Arwani, KH Sya'roni, KH Munawwir, KH Abdul Qadir, KH Damanhuri, KH Saleh Ma'mun, KH Muntaha, dan KH Azra'i Abdurrauf Memasuki paruh abad 20, seiring dengan eksebisi qari' Mesir ke Indonesia, mulai marak berkembangan lagu model Mishri. Pada tahun 60-an pemerintah Mesir mensuplai sejumlah maestro qari' seperti Syeikh Abdul Basith Abdus Somad, Syeikh Musthofa Ismail, Syeikh Mahmud Kholil Al Hushori, dan Syeikh Abdul Qadir Abdul Azim. Animo dan atensi umat Islam Indonesia terhadap lagu-lagu Mishri demikian 
tinggi. Hal ini disebabkan karakter lagu Mishri yang lebih dinamis dan merdu. Keadaan ini cocok dengan kondisi alam Indonesia. Sejumlah qari' yang menjadi elaboran lagu Mishri adalah : $\mathrm{KH}$ Bashori Alwi, KH Mukhtar Lutfi, KH Aziz Muslim, KH Mansur Ma'mun, KH Muhammad Assiry, dan KH Ahmad Syahid. ${ }^{13}$

Beberapa nama lagu sangat dinisbahkan kepada daerah dimana irama tersebut berasal dan sebagian dinisbahkan kepada kelompok yang memperkenalkan irama tersebut. Dikenal lagu Banjakah, Hijaz, Maya, Rakby, Jiharkah, Sika, dan Dukkah. Sementara, dalam tradisi Misri (Mesir) terdapat Bayyati, Hijaz, Shobah, Rashd, Jiharkah, Sika, dan Nahawand.

\section{Bayyati}

Setiap bentuk susunan lagu tilawah Alquran, terutama yang bersifat formal, selalu diawali dan diakhiri dengan irama Bayyati. Lagu Bayyati penutup terdiri dari dua bentuk dan dua tingkatan suara, yaitu Jawab dan Jawabul Jawab.

2. Shobah (Maya)

Lagu Shobah terdiri dari lima bentuk dengan tiga variasi, yaitu Ajami, Mahur, dan Bastanjar. Sementara, untuk tingkatan suaranya ada dua, yakni Jawab dan Jawabul Jawab.

\section{Hijazi (Hijaz)}

Lagu ini terdiri dari tujuh bentuk dan empat variasi, yaitu Kard, Kard- Kurd, Naqrisy, dan Kurd. Sementara, bentuk tingkatan suaranya ada tiga, yakni Jawab, Jawabul Jawab, dan Qarar.

4. Nahawand (Iraqi)

Lagu Nahawand terdiri dari lima bentuk dan dua selingan, yaitu Nuqrasy dan Murakkab. Ciri-ciri variasi Nuqrasy adalah bernada rendah (turun) sedangkan variasi Murakkab bernada tinggi

\section{${ }^{13}$ ibid}


(naik).Adapun tingkat suara Nahawand ada dua, yakni Jawab dan Jawabul Jawab.

\section{Sika}

Lagu Sika terdiri dari enam bentuk dan empat variasi, yaitu Misri, Turki, Raml, dan Uraq. Sementara, tingkatan suaranya ada tiga, yakni Qarar, Jawab, dan Jawabul Jawab.

\section{Rast dan Rasta 'alan Nawa}

Lagu Rast dan Rasta 'alan Nawa selalu berhubungan satu sama lainnya. Jika bacaan dimulai dengan lagu Rast maka mesti dilanjutkan (disambung) dengan Rasta 'alan Nawa. Jenis lagu ini terdiri dari tujuh bentuk dan tiga variasi, yaitu Usyaq, Zanjiran, dan Syabir 'ala ar- Ras. Sementara, tingkat suaranya ada dua, yakni Jawab dan Jawabul Jawab.

\section{Jiharkah}

Lagu Jiharkah terdiri dari empat bentuk dan satu variasi, yaitu Kurdi.Sementara, tingkatan suaranya ada dua, yaitu Jawab dan Jawabul Jawab.

Maqomat tilawatil Quran yang sering pula disebut langgam, irama, atau nagham Alquran adalah seni membaca Alquran dengan nada yang indah namun tetap berada pada kaidah tajwid yang benar. Idealnya, dalam membaca dan menghafal Alquran, seorang muslim juga memperhatikan aspek maqomat yang digunakan. Ilmu maqomat adalah salah satu cabang ilmu dalam mempelajari Alquran di samping tahsin, tajwid, tahfidz, tarjim, dan bidang ilmu lainnya, di mana kesemuanya harus berjalan beriringan. Karena tidak boleh menabrak kaidah tajwid, maqomat menjadi unik dan tidak bisa diwujudkan dalam notasi balok seperti halnya musik atau nyanyian. Hal tersebut membuat pembelajaran maqomat hanya terbatas pada metode Talaqqi (face to face murid dengan guru, murid mengulang bacaan guru) dan sama'i (menyimak bacaan qari lalu menirukannya). 
Secara garis besar, ilmu maqomat tilawatil Quran membahas tujuh jenis langgam / irama yaitu bayati, hijaz, nahawand, syika, rost, shoba, dan jiharkah.

Penerapan nagham sebagai unsur estetika dalam bacaan Alquran sudah tumbuh sejak periode awal Islam. Kendati demikian, sulit untuk melacak seperti apa proses perkembangan nagham tersebut hingga memunculkan berbagai bentuk variannya seperti yang kita dapati hari ini. Hal itu disebabkan tidak adanya bukti yang dapat dikaji.

Ibnu Manzur, seperti dinukilkan oleh Dr Basyar Awad Ma'ruf, al-Bayan fi Hukm at-Taghanni bi Alquran, ada dua teori tentang asal mula munculnya nagham Alquran. Pertama, nagham Alquran berasal dari nyanyian nenek moyang bangsa Arab. Kedua, nagham terinspirasi dari nyanyian budak-budak kafir yang menjadi tawanan perang. Kedua teori tersebut menegaskan bahwa lagu-lagu Alquran pada mulanya memang berasal dari khazanah tradisional Arab.

Tidak ada catatan sejarah yang menjelaskan perkembangan nagham Alquran setelah era tabi'in. Namun, kalangan akademisi Islam meyakini bahwa, transformasi seni baca Alquran berlangsung secara sederhana dan diwariskan turun-temurun dari satu generasi ke generasi berikutnya.

Beberapa metode yang digunakan dalam mewariskan ilmu nagham Alquran dari masa ke masa adalah sima'i (mendengar), talaqqi (menerima dan mengambil pelajaran lewat bimbingan seorang guru), dan musyahafah.

Para qari di dunia sudah tidak asing lagi dengan "delapan maqamat quraniyyah" atau juga biasa dikenal dengan "delapan nagham Alquran". 
Kedelapan varian nagham tersebut ialah Bayyati (Husaini), Sika, Shoba (Maya), Rasta alan nawa, Hijazi (Hijaz), Jiharkah, Nahawand (Iraqi), dan Banjaka (Rakbi).

Setiap qari di seluruh dunia selalu menggunakan satu dari delapan nagham tersebut ketika membaca Alquran.

Bila ditelusuri dari definisinya, ilmu nagham berbeda dengan ilmu qiraah. Jika ilmu nagham dikhususkan un tuk mempelajari seni irama dan lagu-lagu Alquran maka ilmu qiraah lebih difokuskan kepada cara membaca Al quran dengan benar dan tepat. Meski berbeda definisi, dalam praktiknya, ilmu nagham tidak boleh menyalahi ilmu qiraah.

Ulama Muslim kontemporer, Muhammad Musthafa alA'zami, memandang bahwa antara teks Alquran, proses pembacaannya, serta pewahyuannya adalah satu kesatuan yang tidak terpisahkan. Menurutnya, ilmu qiraah yang benar diperkenalkan oleh Nabi Muhammad SAW sendiri, yakni suatu praktik (sunah) yang menunjukkan tata cara bacaan setiap ayat. Aspek ini juga berkaitan erat dengan kewahyuan Alquran.

"Oleh karena itu, antara teks dan cara pengucapan Alquran haram untuk bercerai," tulis al-A'zami dalam buku The History of The Quranic Text From Revelation to The Compilation: A Comparative Studi with The Old and New Testaments.

Hingga abad ke-20, Mesir telah menjadi inspirasi dan merupakan pusat lahir dan berkembangnya budaya maqamat Alquran yang penuh harmoni.Di samping itu, negeri piramida itu juga menempatkan dirinya sebagai saringan yang memisahkan antara musik dan qiraah maqamat nagham Alquran.

"Qari-qari yang lahir di Mesir, seperti Syekh Muhammad Rif'at (1882- 1950), Syekh Mustafa Ismail (1905-1978), dan Syekh Abdul Basit Abdul-Samad (1927-1988) mampu menunjukkan kepada dunia bahwa nagham adalah nyawa dari bacaan Alquran " 
ungkap M Husni Thamrin dalam tesisnya, Nagham Alquran: Telaah atas Kemunculan dan Perkembangannya di Indonesia.

\section{PROFIL HIMPUNAN QARI' QARI'AH MAHASISWA (HIQMAH)}

1. Sejarah Singkat HIQMAH Sulawesi Tengah

Himpunan Qari' dan Qari'ah Mahasiswa yang disingkat dengan HIQMAH berdiri tepatnya pada tanggal 03 Januari 2010, dimana Moment ini bersamaan dengan perayaan Hari Amal Bhakti Kementerian Agama RI. HIQMAH didirikan di kampus Hijau IAIN Palu (dulu bernama STAIN Datokarama Palu). Berawal dari keinginan dan harapan kuat seorang Mahasiswa bernama Syahril Rachman yang juga Qori dan sekaligus sebagai seorang Murattal dan aktivis HMI, Jurusan Dakwah Program Studi Komunikasi dan Penyiaran Islam dan bersama Dosen pembina mata kuliah Ulum Alquran seorang Qori/Khattat dan juga Dosen di Perguruan Tinggi IAIN Palu saat itu.

Latar belakang berdirinya HIQMAH adalah berawal dari keresahan seorang pemerhati ilmu Alquran dan sekaligus sebagai pembiba mata kuliah bersama Mahasiswanya Syahril Rachman, karena melihat kondisi kampus yang Nota Banenya adalah kampus Islam justru minim akan pemahaman dan pendalaman ilmu - ilmu yang terkait dengan Alquran terutama ilmu tajwid atau hukum bacaan al-Qur'an, dan sekaligus sebagai upaya untuk menghimpun para Qari' dan Qari'ah yang ada di kampus saat itu.

Berangkat dari diskusi kecil inilah akhirnya berinisiatif untuk membentuk HIQMAH sebagai organisasi Ekstra Kampus yang menjadi satu wadah untuk mengembangkan minat dan bakat mahasiswa STAIN Datokaram Palu dan Universitas lainnya di Kota Palu, khususnya di bidang seni baca Al-Quran dan seni-seni Islam lainnya. Karena banyak sekali mahasiswa yang belum paham terhadap pemahaman Al-Qur'an dan juga Mahasiswa yang berbakat 
di bidang tilawah, tetapi tidak ada wadah yang dapat mengembangkannya.

Perjuangan untuk mendirikan HIQMAH tidaklah semudah yang dibayangkan karena minimnya dukungan pada saat itu khususnya Mahasiswa. Mereka menganggap tidak penting adanya HIQMAH. Namun tekad yang ditanamkan adalah "Setiap ada kemauan pasti ada jalan dan pertolongan Allah $S W T$ pasti datang bagi setiap orang yang menolong tali agama Allah". Di saat semua orang tidak mendukung, tetapi semangat untuk mendukung penuh agar HIQMAH terbentuk dan menjadi Organisasi yang besar sampai saat ini. Dukungan beliau seraya memberikan titik terang dan angin segar agar tetap semangat dan melanjutkan perjuangan. Pendiri lembaga ini memang memiliki latar belakang studi dari memang terkenal sebagai orang yang menyukai kegiatan seni Islam dan bidang tilawah. Beliau mempunyai semangat untuk menghidupkan dakwah Islam. Akibat bantuan beliaulah hingga akhirnya pendirian HIQMAH menjadi satu diantara lembaga eksternal kampus yang eksis di Kota Palu-Sulawesi Tengah dalam melakukan pembinaan terhadap Mahasiswa khususnya dan Masyarakat Muslim pada umumnya dalam mempelajari seni baca Al-Qur'an dan seni Islami.

Sehingga, seiring berjalannya waktu HIQMAH (Himpunan Qori' dan Qori'ah Mahasiswa) menjadi sebuah Organisasi Kemahasiswaan bersifat Independen yang terdapat di Palu Sulawesi Tengah, yang menjadikan Al-Qur'an dan seni Islami sebagai ruh kegiatan dan orientasi aktivitasnya. Disamping itu juga mengedepankan menejemen organisasi yang harus dimiliki oleh setiap kader.

Dalam perjalanan Organisasi ini, Ketua Umum pertama adalah Syahril Rachman dan juga salah satu pendiri. Posisi ini menjadikan setiap pikir dan langkahnya berupaya untuk mendapatkan gagasan baru demi tercapainya Tujuan yang di cita- 
citakan dengan menjadikan fungsi HIQMAH sebagai Organisasi Perkaderan dan menjadikan perannya sebagai Organisasi Dakwah. Dengan menjadikan perannya sebagai Organisasi Perkaderan, diharapkan mampu menciptakan kader-kader terbaik untuk melanjutkan tongkat estafet kepemimpinan secara berkelanjutan. Sementara dengan dasar perannya sebagai Organisasi Dakwah, HIQMAH menjadi tugas bagi para kader untuk mendakwahkan dan memasyarakatkan nilai-nilai Al-Qur'an di tengah-tengah masyarakat kampus khususnya dan masyarakat muslim pada umumnya, sebagai realisasi menjawab keresahan para pendiri kala itu.

Pasang surutnya roda organisasi sangat dirasakan oleh kepengurusan awal, baik di internal maupun di Eksternal HIQMAH. Namun itu tidak menjadi alasan untuk bisa membesarkan organisasi. Telah banyak putra putri kader terbaik yang mengharumkan dan memberi warna tersendiri terhadap dan juga daerah di Sulawesi Tengah, baik di kancah lokal maupun nasional yang walau pun bukan seluruhnya hasil penggemblengan. Di antara pengurus yang memiliki dedikasi terhadap perkembangan Himpunan Qari dan Qariah Mahasiswa di antaranya:

1. Syahril Rachman, aktifis kajian ilmu Alquran khususnya dalam Musabaqah Makalah ilmiyah Alquran.

2. Mikdan, seorang Qori Nasional Alumni STAIN Palu yangmampu bersaing di beberapa MTQ Nasional hingga saat ini.

3. Mahfud Kasim, alumni STAIN Palu dan Hafidz 10 dan 20 Juz yang telah mengharumkan nama Daerah di kancah MTQ Nasional.

4. Iswadi dan Syarifah, alumni STAIN Palu yang sampai hari ini bersaing dikancah MTQ Nasional pada lomba Kaligrafi Al-Qur'an. 
5. Ningsih, seorang Qori'ah mampu mengisi posisi 6 besar pada MTQ Tingkat Nasional di Gorontalo.

6. Mukti Alie, seorang mahasiswa IAIN Palu diut us sebagai peserta Syarhil Qur'an pada MTQ Nasional di kota Ambon 2012.

7. Fendi Pradana, mahasiswa Alumni Untad sebagai utusan peserta Fahmil Qur'an pada MTQ mahasiswa Tingkat Nasional di Aceh 2011.

8. Suryani, peserta M2IQ mantan Mahasiswi STAIN Palu dan juga Aktivis PMII Palu telah menjadi utusan Prov. Sulteng pada MTQ Nasional di Kota Batam. Dan masih banyak lagi qori qori'ah, hafidz dan hafidzah, mufassir dan mufassirah, khattat dan khattatah, penulis karya ilmiah Al-Qur'an, dan masih banyak lainnya yang menjadi juara pada MTQ, di berbagai tingkatan.

Perlu pahami bahwa HIQMAH tidak hanya mengkhususkan dirinya untuk para kader yang sudah mahir dalam tilawah, sholawat, marawis, qosidah dan sebagainya, tetapi juga membuka diri bagi mereka yang belum punya basic dan ingin mendalami pelatihanpelatihan yang diselenggarakan. Selain mendalami bidang seni suara dan seni Islami, HIQMAH juga membekali para anggota dan pengurusnya dengan pengetahuan organisasi. Sehingga diharapkan kader-kader tidak hanya pandai dalam seni suara dan seni Islami, tapi diharapkan bisa menjadi organisator yang handal.

Motto : "Mengarungi Samudera Alquran"

\section{Visi Dan Misi HIQMAH}

Visi : "Menjadi lembaga yang membentuk insan akademis yang beriman dan bertaqwa kepada Allah SWT. Yang memiliki wawasan dan kecintaan terhadap Al-quran dan seni islami serta mampu mengembangkan potensi dan keterampilan seni 
islami tersebut sebagai media dakwah di tengah-tengah masyarakat."

\section{Misi HIQMAH :}

Misi:

- Membina dan mengembangkan potensi dan kreatifitas seni islami mahasiswa.

- Membina para mahasiswa dalam mendalami dan mengaplikasikan al-qur'an dalam kehidupannya.

- Memasyarakatkan seni islami di tengah-tengah masyarakat kampus khususnya dan masyarakat muslim umumnya.

\section{Tujuan berdiri HIQMAH}

HIQMAH memiliki tujuan, yaitu; "Terbinanya insan akademis yang beriman dan bertaqwa kepada Allah SWT. Yang memiliki wawasan dan kecintaan terhadap Al-quran dan seni islami serta mampu mengembangkan potensi dan keterampilan seni islami tersebut sebagai media dakwah di tengah-tengah masyarakat."

Sebagaimana dijelaskan di atas bahwa organisasi ini adalah merupakan Rumusan dari Misi HIQMAH maka dapat dirumuskan dalam 3 kualitas insan :

1. Insan Akademis

Berpendidikan tinggi, mampu berfikir rasional, objektif dan kritis. Memiliki kemampuan teoritis, mampu merformulasikan apa yang diketahui dan apa yang dirahasiakan dan dia menghadapi suasana disekelilingnya dengan penuh kesadaran.

Sanggup berdiri sendiri dengan ilmu yang ia miliki sesuai dengan jurusan ilmu yang dipilihnya baik secara teoritis maupun teknis dan sanggup berkerja secara ilmiah yaitu secara bertahap, teratur, mengarah pada tujuan sesuai dengan prinsip-prinsip perkembangan.

2. Insan Beriman dan Bertaqwa Kepada Allah SWT. 
Menyakini Allah SWT adalah Tuhan yang Esa, Tuhan yang Satu, tidak ada tuhan selain Allah. Kemudian menjalankan segala yang diperintahkan oleh Allah SWT. Dan menjauhi segala yang dilarang oleh Allah SWT, dengan penuh kesadaran dan keikhlasan semata-mata hanya ingin mencari Ridha Allah SWT.

3. Insan Berwawasan, Cinta Al-Quran dan Seni Islami.

Berpengetahuan luas, Ikhlas dan sanggup berkarya demi kepentingan orang banyak atau sesama umat manusia. Sadar membawa tugas insan berwawasan bukan hanya membuat dirinya baik tetapi membuat keadaan disekelilingnya jadi baik. Insan akademis beriman dan bertaqwa adalah insan yang pasra citacitanya yang ikhlas mengamalkan ilmunya untuk kepentingan sesamanya.

Islam telah menjiwai dan memberi pedoman pola pikir dan pola lakunya tanpa memakai merek islam, insan akan jadi pedoman dalam berkarya dan mencipta sejalan dengan mission Islam dengan demikian islam telah manifestasi dan menjiwai karya-karyanya.

Cinta terhadap Al-Qur'an adalah manifestasi cinta kita kepada Allah dan Rasulnya, rasa tanggung jawab dan rasa taqwa kepada Allah SWT, yang menggugah untuk mengambil peran akif dalam mendakwahkan nilai-nilai Al-Qur'an dan seni Islami juga mewujudkan masyarakat adil makmur yang diridoi Allah SWT.

\section{Temuan Penelitian}

Kegiatan pelatihan tahsin alquran yang dilaksanakan oleh lembaga Himpunan Qari dan Qariah Mahasiswa Sulawesi Tengah terlaksana secara multi program. Kegiatan - kegiatan terintegrasi melalui program yang dilaksanakan oleh masing-masing unit.

1. Kegiatan Training Kader

Program perdana yang dilaksanakan oleh lembaga Hiqmah pada setiap kader yang akan bergabung dalam lembaga ini adalah kegiatan pengkaderan yang dituangkan dalam agenda Training 
Kader (TRIK). Kegiatan ini diciptakan sebagai wahana perekrutan anggota baru. Dalam kegiatan ini diharapkan peserta dapat memahami program-program yang akan dilaksanakan oleh lembaga di masa mendatang. ${ }^{14}$

Training kader dilakukan melalui persiapan-persiapan oleh pengurus dan anggota aktif lainnya. Proses pendaftaran peserta dengan kewajiban mengisi bidang-bidang yang menjadi favorit untuk dikembangkan lebih lanjut. Pilihan yang diberikan meliputi tahsin Alquran di bidang tilawah atau seni baca Alquran, bidang hafalan atau tahfiz Alquran, bidang kaligrafi Alquran, bidang pemahaman atau makalah Ilmiyah Alquran atau bidang pengembangan bakat seni Islam lainnya. ${ }^{15}$

Dalam agenda kegiatan ini, peserta training kader mendapatkan pengantar tahsin Alquran yang disampaikan oleh para alumni HIQMAH maupun narasumber yang profesional di bidangnya. Tilawah Alquran disampaikan materi tentang tingkatan - tingkatan suara dan irama di masing-masing nagham.

Peserta mendapatkan latihan berupa pengenalan irama-irama yang berkembang di bidang seni tilawah baik didasarkan pada perkembangan irama yang disampaikan oleh qari nasional maupun qari dari berbagai negara lainnya. Irama tersebut meliputi irama bayati, irama nahawan, irama rash, irama shabah, irama jiharka dan berbagai tingkatan lainnya.

Anggota yang telah melalui proses training kader dan dinyatakan telah lulus maka kegiatan selanjutnya adalah Training Manajemen Organisasi (TMO). Pada bagian ini anggota yang

\footnotetext{
14 Wawancara bersama pendiri Hiqmah Sulawesi Tengah Syahril Rahman pada tanggal 10 Agustus 2016

15 Wawancara bersama Ketua Umum Hiqmah Sulawesi Tengah Mufrianda, S.Pd. pada tanggal 05 Oktober 2016 pada jam 17.00 dalam sela sela persiapan pembukaan kegiatan.
} 
tergabung dalam struktur kepengurusan dan yang menjadi anggota penuh Hiqmah diharuskan mengikuti pelatihan penataan organisasi yang dituangkan dalam kegiatan training manajemen Organisasi. Kegiatan yang dilaksanakan adalah penetapan program dan alokasi waktu yang ditentukan dalam proses pelatihan selanjutnya, baik bersifat waktu yang pendek, menengah maupun program tahunan. Dapat dikatakan bahwa proses Training manajemen Organisasi merupakan tonggak awal dan penting dalam pelaksanaan program selanjutnya dalam tahsin Alquran.

2. Latihan Rutin Tahsin Alquran

Kegiatan rutin program tahsin Alquran yang diselenggarakan oleh HIQMAH adalah pelatihan Tilawah secara berkesinambungan dan Tahfidz Qur'an. Dalam kegiatan ini, materi yang diberikan dan tersajikan bersifat pendalaman. Materi tajwid yang disampaikan berkaitan dengan tehnik dan praktek baca yang disampaikan oleh pelatih tilawah atau tahfiz. ${ }^{16}$

Pada latihan tilawah, peserta latihan mendapatkan dasar seni tilawah berbarengan dengan cara membaca lafadz-lafadz ayat Alquran dengan berdasarkan hukum-hukum bacaan. Tahsin Alquran yang dimaksudkan adalah menyampaikan ayat-ayat Alquran dengan berdasarkan makharij huruf (menyebutkan huruf dengan berdasarkan tempat keluarnya), menyampaikan hukum-hukum bacaan Alquran yang meliputi hukum bacaan Izhar, Ikhfa, Iqlab, Idgam, Hukum bacaan mim sukun, bacaan yang tebal atau tipis dan sifat-sifat huruf lainnya.

Dalam latihan tilawah Alquran, disamping memahami hukum bacaan dan irama, hal terpenting juga adalah penguasaan nafas. Tangga nada dimulai dengan pengenalan bahwa dalam

${ }^{16}$ Wawancara bersama salah seorang pelatih sekaligus sebagai pengurus Hiqmah Sulawesi Tengah Rizka Khairiyah pada tanggal 20 Oktober 2016 menjelang sessi latihan di gedung SBSN IAIN Palu. 
melagukan ayat Alquran didahului dengan mengeluaran suara bagian bawa (suara perut). Nada dengan suara bawa ini dipakai dalam jenis lagu bayati dengan tingkatan awal maqam, bayati nawa, yang dilanjutkan dengan lagu nahwan, sika, rast dan jiharka.

Maka sesekali penyajian bimbingan tilawah tersebut disertai dengan motivasi peserta untuk melakukan hal yang lebih baik dan terus melakukan latihan untuk mencapai prestasi yang lebih baik. Prestasi pada kegiatan bacaan seni / nagham dimaksudkan adalah prestasi semangat untuk selalu melakukan peningkatan mutu tilwah.

3. Kegiatan Khat Alquran

Kegiatan pelatihan khat Alquran adalah bagian dari kegiatan Tahsin Alquran. Himpunan Qari dan Qariah Mahasiswa melaksanakan kegiatan ini diharapkan kader memiliki skill yang dari sisi penulisan Alquran secara baik dan benar. Menulis ayat-ayat Alquran dengan berdasarkan kadiah yang berlaku dalam kaidah rasm utsmani, Rasm atau bentuk tulisan yang disepakati ulama yang berisi kaidah-kaidah /panduan hukum dalam penulisan ayat Alquran.

Bentuk pengenalan dan bahan pengajaran yang diberikan adalah bentuk-bentuk tulisan dengan berdasarkan kaidah-kaidah masing-masing tulisan dimaksud. Bentuk tulisan tersebut adalah:

1. Khat naskh,

2. Khat tsuluts,

3. Khat diwani,

4. Khat riqi,

5. Khat farisi

6. Khat kufi.

Materi yang ditekankan adalah perbedaan yang mendasar dari masing-masing tulisan tersebut. Materi tersebut adalah berkisar kemiringan atau posisi pena yang digunakan. Kemiringan dari khat tersebut memiliki perbedaan antara naskhi, tsulutsi yang berbeda dengan tulisan riqi dan farisi. 
Latihan diawali dengan cara pemilihan alat tulis yang tepat. Alat yang digunakan adalah jenis pakis tua dan awet dalam penggunaannya. Pakis ini sering disebut dengan handam. Namun alat tulis yang lain pun disarankan dapat dipergunakan, seperti bambu atau kayu. Bagi pemula disarankan pula memakai pensil yang memiliki mata pena yang tebal.

Tinta yang baik juga mempengaruhi hasil latihan. Tinta yang sering dipakai adalah tinta cina. Tetapi tinta yang lain pun dapat direkomendasikan sebagai tinta yang dapat dipergunakan, seperti tinta print. Namun hal yang membedakan adalah hasil torehan yang berkualitas.

Menurut Faisal, ${ }^{17}$ tehnik penyampaian materi diawali memberikan dasar-dasar yang harus disiapkan dan tehnik yang membedakan antara bentuk tulisan. Misalnya, tulisan tsuluts dan naskhi memiliki perbedaan dengan tulisan riqah dalam menoreh suatu pena. Antara bentuk tulisan farisi berbeda karakter posisi pena dengan diwani atau diwani jali.

Lebih lanjut dikatakan bahwa tehnik dasar yang dilakukan oleh seorang penulis adalah menyiapkan bentuk bentuk tulisan yang sudah berkualitas dari sisi kaidah disamping menyiapkan bentukbentuk huruf hijaiyah dan bentuk huruf ketika pada posisi tengah serta pada posisi tertentu dalam susunan kalimat yang hendak ditorehkan.

\footnotetext{
${ }^{17}$ Wawancara bersama Faisal seorang pelatih dan sekaligus sebagai pembina di Sanggar Alhasyimi Palu pada bidang Naskhi yang dilaksanakan pada tanggal 01 Nopember 2016.
} 
Tamrin, Pola pembinaan Tahsin Alquran...|349

\section{KESIMPULAN}

Dari uraian-uraian pembahasan tersebut, penulis dapat menyimpulkan sebagai berikut:

1. Tahsin Alquran dalam kebahasaan berarti upaya untuk memperbaiki, menghiasi, membaguskan, memperindah atau membuat lebih baik dari bacaan Alquran. Yang dalam ilmu Alquran biasa dilaksanakan dengan pembacaan Alquran secara tajwid. Sedangkan tartil Alquran adalah upaya membaca Alquran secara baik sesuai dengan tata aturan bacaan Alquran berdasarkan makharij huruf, ahkam huruf dan shifat huruf dengan tetap mengedepankan hak-hak yang ada dalam ayat-ayat Alquran.

2. Bentuk pembinaan Alquran di lembaga pendidikan yang berkembang saat ini mengikuti bentuk pembinaan lazim yang digunakan oleh para guru tilawah. Penerapan lagu Makkawi yang digemari oleh sebagian besar qari qariah menjadi dasar untuk mengembangkan sesuai dengan irama di Mesir dan tidak menutup kemungkinan penerapan Mishri yang berkarakter dinamis dan merdu tetap diterapkan.

3. Himpunan Qari dan Qariah Mahasiswa yang disingkat dengan HIQMAH Sulawesi Tengah adalah lembaga yang didirikan sejak awal memiliki komitmen untuk berdakwah dalam bidang seni baca tulis Alquran. Bentuk pembinaan yang dilakukan sebagaimana lazimnya dalam lembaga keorganisasian menerapkan sistem kaderisasi yang diramu dalam acara training kader sebagai awal pengenalan tahsin Alquran. Kegiatan rutin pembinaan selanjutnya adalah kegiatan latihan tilawah dengan penerapan jenis-jenis lagu dan irama. 
350 |Rausyan Fikr, Vol. 12 No.2 Desember 2016: 315- 350

\section{DAFTAR PUSTAKA}

Alhilali, Majdi Agar Alquran Menjadi Teman, Jakarta: Serambi Ilmu Semesta, tth.

Assirjani, Raghib (terjemahan) Sumbangan Peradaban Islam kepada Dunia, Pustaka Alkautsar.

Bin Katsir, Imaduddin Abul Fida Ismail bin al-Khatib Abu Hafs Umar bin Katsir asy-Syafi'i al-Quraisyi ad-Dimasyqi, Tafsir Alquran al-Azim almasyhur bi tafsir Ibnu Katsir

Herwibowo, Bobby Tehnik Quantum Alquran, 9 Cara Praktis Menghafal Alquran, Jakarta: Gema Insani Press, 2005.

Imron, Arifin, penelitian kualitatif Dalam Ilmu-ilmu Sosial dan Keagamaan, Cet. III, Malang:Kalimasada Press, 1996.

Ismail, Bustaman Mengenal Nagham (Irama) Al Quran dan Kilasan Sejarahnya

Mu'jam Al Wasith

Qamus Al-Munir

S. Khothob, Keutamaan Membaca Alquran dalam Alquran dan Terjemahannya, Jakarta: Dunia Purtaka, tth.

Shahih al-Bukhari, Jami' Shagir 